\title{
Entre o cristianismo e o marxismo: hermenêutica de uma trajetória
}

Between Christianity and Marxism: hermeneutics of a trajectory

Edison Lucas Fabrício*

RAMPINELLI, Waldir J. Evangelho e Manifesto na Religião e na Política. Florianópolis: Insular, 2016.

Palavras-chave: Waldir Rampinelli; catolicismo; marxismo

* Mestre em história pela Universidade Federal de Santa Catarina, doutorando em História (UFSC), Brasil E-mail:edisonlucasf@hotmail.com 
"Eis um livro que vale a pena ser lido". Esta é a primeira frase do prefácio do ilustre teólogo brasileiro, Leonardo Boff, ao livro do professor Waldir Rampinelli, Evangelho e manifesto na política e na religião. Ninguém mais autorizado que o mais renomado pensador da Teologia da Libertação para fazer esta indicação de leitura. As suas palavras devem ser levadas em consideração, pois desde o século XIX encara-se a leitura como um esforço complexo. Ler, nos ensina Dilthey, é um empreendimento hermenêutico, é a tentativa empática de compreender o outro. Lição tão ou mais valiosa se tratando de um livro que transita entre a história e a memória, de uma escritura que possui um caráter autobiográfico e, ao mesmo tempo, a ambição de narrar momentos pontuais da segunda metade do século XX. Dilthey escreve que "a biografia possui um significado eminente para a compreensão da grande conexão do mundo histórico", e é nestes fragmentos biográficos do professor Rampinelli que encontramos "a conexão original entre a própria vida e a história", vida que flui neste livro, nas palavras de Leonardo Boff, "como as águas de um riacho de montanha catarinense". (p. 13). Leonardo Boff sabe o que diz, à semelhança do professor Rampinelli é também catarinense.

A perspectiva de escrita de Rampinelli é apresentada já nas primeiras páginas. O olhar é marxista e benjaminiano. Trata-se de uma narrativa inconformada, mas generosa, denunciadora, mas que não perde a ternura, que vê a barbárie nos documentos de cultura, mas que não se resigna, antes busca elaborar uma história à contrapelo, "para que as cicatrizes apareçam com mais nitidez" (p. 16), uma história desde abaixo, na perspectiva dos vencidos. Buscar inspiração em Walter Benjamim é deparar-se com um dos maiores desafios já prescritos ao historiador, a da redenção do passado, ele afirmava que "o dom de despertar no passado as centelhas da esperança é privilégio exclusivo do historiador convencido de que também os mortos não estarão em segurança se o inimigo vencer" ". É o mesmo Benjamim, que noutro texto via com nostalgia o declínio da arte de narrar, fruto do próprio declínio da experiência. Se narrar era trocar experiências, com o empobrecimento da experiência a própria arte da narrativa estava ameaçada ${ }^{3}$. Esta arte de narrar é aqui retomada com vigor pelo professor Rampinelli. Assim, a inspiração benjaminiana, é a linha mestra que orienta todo o livro, dividido em 4 pequenos capítulos: "1968"; "Uma lagoa mansa e azul"; "evangelho e manifesto"; "As aberrações da Igreja". Por fim, na conclusão, o autor expõe suas razões de ter aderido o sacerdócio, e num epílogo, as atividades acadêmicas e políticas.

"1968" é o primeiro capítulo e trata não apenas de um ano fulcral para a história, mas de todo um contexto de grandes mudanças. O texto é uma grande aula de história da América Latina. É o momento da expansão dos ideais da Revolução Cubana para o continente, de ampliar as possibilidades do Concílio Vaticano II no encontro do Episcopado em Medellín. 1968, lembra 
Rampinelli, é o ano do Massacre de Tlatelolco, onde mais de mil estudantes mexicanos foram mortos na Praça das Três Culturas. É deste período também a guerrilha na Guatemala, país construído em solo maia, onde se acredita que "as árvores respiram o hálito das pessoas que habitam as cidades soterradas pelos conquistadores espanhóis" (p. 22). Daí o costume de assentar-se sob as árvores para escutar o conselho dos antepassados: "ler nas rugas dos mais velhos é como retomar o caminho. Nas terras maias, a força não vem de cima, mas de baixo" (p. 23). Nada mais hermenêutica que tal perspectiva. Um dos autores fundamentais para a Teologia da Libertação, Paulo Freire, já enfatizava a importância do ato de ler o mundo que nos cerca, pois, nas suas palavras, "a leitura do mundo precede a leitura da palavra"4.

O sopro de mudanças que embalou 1968 é o horizonte utilizado por Rampinelli para disparar flashes sobre a história do movimento Sandinista na Nicarágua, para compreender os conflitos de El Salvador, terra do inesquecível Óscar Romero, da Colômbia de Camilo Torres. São os tempos da Operação Condor no Cone Sul, de ditaduras militares sanguinárias com o apoio estadunidense no contexto da Guerra Fria. No Brasil, 1968 é o ano do AI-5, que marcou toda uma geração de jovens.

É neste ano de 1968 que o autor iniciou a sua formação em filosofia e teologia em Curitiba, uma "cidade conservadora, mas libertadora". Das vivências deste período de formação, dos debates na universidade, de Vida e Morte Severina no Teatro Guaíra, dos livros proibidos, Rampinelli parece ter guardado marcas indeléveis. Quando sacerdote nas margens da Lagoa do Imaruí lembrava que "o pescador saqueado tem muito do nordestino retirante. A mesma cabeça grande que a custo se equilibra, mesmo ventre crescido sobre as pernas finas [...]" (p. 55). É também deste período de formação as lembranças do impacto da Teologia da Libertação no então jovem seminarista, as leituras de Leonardo e Clodovis Boff, o exemplo pastoral de Dom Helder, Dom Pedro Casaldáliga, Dom Paulo Evaristo Arns.

É ainda destes anos de chumbo a lembrança do Projeto Rondon, vivenciado em Cachoeira do Arari, na Ilha de Marajó. Era o primeiro encontro com o "Brasil profundo", com os pescadores, esses trabalhadores do mar que fariam parte da vida em Imaruí, com a experiência da pobreza, do "latifúndio que abraçava o povoado e estrangulava a vida" (p. 35). Das experiências com os mais pobres nesta época de formação Rampinelli ainda relaciona os cursos de férias realizados com os camponeses do sudoeste paranaense, no período de férias. Os seminaristas de Curitiba eram convidados por padres belgas, seguidores da Teologia da Libertação, que trabalhavam na região de Francisco Beltrão para ministrar os cursos. "O objetivo era criar uma consciência que levasse as pessoas a uma práxis política que consistia em lutar pelo fim da ditadura militar, pelo retorno da democracia e por uma distribuição justa da riqueza. Eram anos de terror de Estado" (p. 37). 
"Uma lagoa mansa e azul" é o segundo capítulo. Nele o autor narra sua experiência já como sacerdote em Imaruí, cidade de pescadores no litoral-sul de Santa Catarina. Formada por pequenos povoados, por colinas e caminhos serpenteados, Imaruí era o lugar onde os pescadores ganhavam e perdiam a vida, onde no amanhecer entregavam "ao atravessador o suor gelado da madrugada. [...] E assim, de trabalho em trabalho, vai vendendo, a cada dia, um pouco da sua vida" (p. 39). À época de seu sacerdócio em Imaruí, Rampinelli se deparou com a força política da oligarquia local, que desde a década de 1930 mantinha a hegemonia no governo do município. Para o jovem padre, em 1974, optar pelos pobres era confrontar-se com os poderosos da cidade, aqui a religião ia além da visão de Marx e Engels, deixava de ser o ópio do povo para "construir um terreno no qual desabrocha uma tomada de consciência que leve à luta de classes em suas diversas configurações" (p. 46).

Ao longo deste capítulo, Waldir Rampinelli narra seu difícil trabalho junto à gente pobre e explorada de Imaruí, pessoas "cujas rugas têm muito o que dizer" (p. 50). Nas missas, nas procissões, e principalmente pelo rádio, o objetivo era a organização popular. Afinal, "os debaixo nada tem a perder, a não ser seus grilhões". Nas grandes aglomerações religiosas, o discurso da libertação do padre não poupava a oligarquia local, sempre na busca de visibilidade política, de angariar algum bem simbólico junto à multidão, "os buscadores de lã voltavam sempre tosquiados e de mãos vazias" (p. 54).

"Evangelho e Manifesto" é o terceiro capítulo do livro. Nele, o autor discorre sobre a segunda etapa do trabalho em Imaruí, já não se tratava mais de apenas denunciar as injustiças, mas de partir para a conscientização e organização dos líderes comunitários. Criou-se, então, a Escola de Formação de Agentes de Pastoral. Ela foi o instrumento para congregar líderes das dezessete comunidades do município através de aulas de História, Política, Sociologia, Cultura Popular, etc. Receosos, apreensivos, esperançosos e entusiasmados, eram muitas as sensações experimentadas pelos participantes das palestras. Aos poucos, mesmo os mais simpáticos à oligarquia local viam a necessidade de tomar partido ao lado dos desvalidos. A experiência com a liderança comunitária levava em consideração as palavras de Fidel Castro proferidas na visita ao Chile de Allende: "há dez mil vezes mais coincidências do cristianismo com o comunismo [Evangelho e Manifesto] do que pode haver com o capitalismo" (p. 61).

Neste capítulo Rampinelli ainda faz uma ácida crítica à Igreja Católica: "A hierarquia eclesiástica é conservadora, castradora, alienante. Transforma o padre ou a freira em uma peça da grande engrenagem multinacional que é a Igreja com sede no Vaticano" (p. 62). Daí que a formação sacerdotal seja uma das principais causas da falta de solidariedade entre os próprios sacerdotes, sendo que a maioria vai "falando de amor sem tê-lo vivido, $[\ldots]$ vai dizendo de Deus sem tê-lo visto no outro" (p. 65). O desencanto com a Igreja fez com que 
Rampinelli solicitasse a dispensa do sacerdócio em 1978, mesmo com o risco de ser estigmatizado de apóstata, como outros padres o foram. Outros fatores o levaram a nutrir aversão pelo catolicismo institucional, como a situação de abandono de padres que dedicaram a vida inteira à Igreja, e a emergência de novos movimentos eclesiais, como o da Renovação Carismática, caracterizado pelo individualismo e pelo desprezo da perspectiva de emancipação social, chegando a ser antievangélico. Estes já eram os anos de João Paulo II, um pontificado que ficou conhecido pelo conservadorismo, pelo acobertamento dos escândalos de pedofilia, pela sabotagem à Teologia da Libertação na América Latina e pelo silenciamento diante das ditaduras militares do continente-muitas delas prestigiadas com visitas oficiais, como a do Chile de Pinochet.

É neste mesmo tom crítico que se inicia o quinto capítulo, "As aberrações da Igreja". A primeira a ser destacada é a instituição do celibato. Para o autor, esta ordenança esta na raiz do processo de acumulação da Igreja, que não quer ver sua riqueza distribuída em forma de herança aos filhos dos sacerdotes. O celibato seria também uma das causas imediatas da pedofilia, pelas distorções psíquicas que causa nos padres. Aqueles que não conseguiam cumprir o voto do celibato, na visão do autor a maioria dos sacerdotes, acabavam por relacionarse com a empregada da casa paroquial, "entre ambos se dava uma relação de grande desigualdade intelectual, econômica, política, social, cultural e sexista, pois um mandava e a outra obedecia" (p. 75).

A segunda aberração produzida pela Igreja teria sido sua participação no processo colonial da América Latina, dele teria saído "mais forte, mais rica, mais abastada e mais poderosa" (p. 76). A Igreja teria participado dos dois maiores crimes praticados contra a humanidade, a "conquista espiritual", isto é, a aniquilação de culturas milenares, de toda uma cosmovisão que integrava o homem, a natureza e seu sistema moral, político e religioso. Concomitante ao primeiro crime, o segundo foi "o uso e apoio da escravidão negra e indígena" (p. 78).

A terceira aberração denunciada por Rampinelli é o caso recorrente das chamadas "aparições de Maria", isto é, o uso político daquela mulher pobre e simples da Palestina do primeiro século. Tais aparições sempre tiveram um caráter marcadamente político-ideológico, a começar por Nossa Senhora de Guadalupe, um dos instrumentos mais poderosos da conquista espiritual do México. No entanto, é em França e em Portugal que os casos de aparições ganham novos contornos. Nossa Senhora de Lourdes torna-se o símbolo da luta contra o secularismo e o laicismo na França a partir de 1858, país de que passava por intenso processo de descristianização após o triunfo da revolução. Em Portugal, é Nossa Senhora de Fátima que a partir de 1917 passa a ser a grande combatente do laicismo da I República. O golpe de Estado de 1926 e a ascensão do salazarismo tiveram em Nossa Senhora de Fátima uma poderosa aliada, era o fim do "divórcio entre Estado e Igreja". O Estado reconheceu 
oficialmente as aparições em Fátima e a virgem passou a abençoar a abençoar as instituições do Estado Novo português, ser a "padroeira da Guerra Fria na sua estratégia de luta contra o comunismo, patrona da diplomacia portuguesa em suas articulações pela manutenção do império colonial ultramarino e protetora dos soldados enviados à África para matar os negros que se levantaram em defesa de suas independências" (p. 86).

"Por que, então, me tornei padre?" é a questão que intitula a conclusão do livro. Se a narrativa do livro inicia em 1968, o período do seminário, a conclusão é uma explicação de como tudo isso principiou, é um recuo às lembranças da infância. Rampinelli lembra que aos nove anos foi colocado num internato. Quando de sua primeira tentativa de libertar-se do seminário fora "ameaçado com o trabalho duro e penoso das lides da roça e do campo. E eu era filho de comerciante. [...] Amedrontei-me profundamente com a desclassificação de uma classe a outra" (p. 89).

Rampinelli lembra que era um sinal de prestígio para a família ter um filho sacerdote. E o seminário aparecia como uma opção de formação barata, às vezes até gratuita para os meninos que vinham do interior. Da quase compulsória escolha pelo sacerdócio até a "despadrização" foi um processo de muitos anos, apoiado somente pelo avô. "Despadrizei-me porque não acreditava na fé sem a razão. Muito menos na pesada e corrupta hierarquia eclesiástica. Uma verdadeira máfia que vende esperança sem tê-la" (p. 91). As palavras de Rampinelli são de desencanto e não escondem o ressentimento de uma infância roubada, que talvez tivesse outro rumo que não o clerical. "Saído dessa instituição, continuei com o mesmo trabalho de libertação e de emancipação das pessoas, mas agora preparado teoricamente, não orientado pelo Nazareno, mas pelo Velho Marx, muito mais consistente, muito mais objetivo, muito mais revolucionário [...]" (p. 92).

Rampinelli assinala que durante algum tempo não falara de seu passado, queria mesmo era esquecê-lo. No entanto, várias situações e pessoas o levaram a reavaliar esta posição, sendo a recente apresentação do Memorial de Atividades Acadêmicas para acesso à carreira de professor titular da UFSC uma delas. Naquela ocasião a banca lhe recomendou a publicação das experiências anteriores e paralelas à atividade de docência no ensino superior, como a atividade pastoral em Imaruí. Rampinelli enfatiza a hesitação inicial, mas cedeu ao registrou no livro que agora temos em mãos. "Orgulho-me deste passado e quero transmiti-lo aos meus filhos e a quem queira ler [...]” (p. 93).

Narrar experiências passadas, trabalhar a memória e o esquecimento são tarefas cruciais da hermenêutica do si. Paul Ricoeur, leitor de Dilthey e Benjamin, e uma das maiores referências da tradição hermenêutica, assinala que humanizamos o tempo quando o narramos, quando retratamos a experiência de forma narrativa e quando the damos significado. Num de seus últimos livros, $O$ si mesmo como um outro, o autor fala da hermenêutica do si e da importância 
do ato de narrar para a constituição da identidade pessoal: "a compreensão do si é uma interpretação; a interpretação de si, por sua vez, encontra na narrativa, entre outros símbolos e signos uma mediação privilegiada [...]. É pela escala de uma vida inteira que o si procura sua identidade" 5 A narrativa do professor Rampinelli se enquadra também nessa perspectiva, a do encontro e exteriorização do si mesmo, do enfrentamento das memórias pessoais e da composição de uma narrativa que, acima de tudo, é uma compreensão da constituição da própria identidade. E não é fortuito que em muitos momentos se deparasse com a hesitação, o receio, até encontrar a aceitação e a positivação das memórias pessoais.

A derradeira parte do livro, o epílogo, narra as atividades acadêmicas e políticas. O mestrado foi realizado na Universidade Nacional Autônoma do México e a dissertação teve como título Análisis de la política exterior brasileña hacia América Latina (1964-1985). Trata-se de um trabalho defendido em 1991 sobre a política externa brasileira durante a ditadura militar. A pesquisa de doutorado, ainda na perspectiva das relações internacionais, versou sobre o apoio do governo de Juscelino Kubitscheck ao imperialismo português. Nesta pesquisa, o autor não tratou apenas de evidenciar o apoio da diplomacia brasileira na ONU em prol das posições colonialistas lusitanas, mas abordou a importância do sociólogo brasileiro Gilberto Freyre e sua tese do lusotropicalismo na legitimação do colonialismo português. A tese foi publicada em formato livro pela editora da UFSC, sob o título As duas faces da moeda - as contribuições e JK e Gilberto Freyre ao colonialismo português.

Dilthey nos ensina que "a célula original do mundo histórico é a vivência, na qual o sujeito se encontra em interação recíproca de vida com seu meio"6. Este livro do professor Rampinelli é um relato de vivências, uma narrativa carregada de subjetividade, onde a memória e a história se encontram e fazem aflorar sentimentos, paixões, contradições e esperanças. A leveza da escrita e o pequeno número de páginas não devem enganar o leitor, trata-se de uma escritura de erudição, que navega pela história e traz à bordo autores como Marx, Tolstói, passando por Durkheim, os brasileiros João Cabral de Mello Neto e Victor Nunes Leal, até chegar em Walter Benjamin, e tantos outros que ajudam a alimentar a narrativa. A infância marcada pela religiosidade, a juventude e as recordações da formação, o sacerdócio junto aos pescadores, a militância política e intelectual nos últimos 35 anos de magistério, são retratos com vigor e beleza literária. Walter Benjamin enfatizava que "o grande narrador tem sempre suas raízes no povo, principalmente nas camadas artesanais" $"$. Das experiências com os pescadores de Imaruí, Waldir Rampinelli deve ter retido a memória do trabalho artesanal de consertar redes e tecer tramas, experiência análoga ao entrelaçamento de frases, palavras, lembranças e esperanças, presente neste livro. 


\section{Notas de Fim}

1 DILTHEY, Wilhelm. A construção do mundo histórico nas ciências humanas. São Paulo: Editora da UNESP, 2010, p. 241.

2 BENJAMIN, Walter. Sobre o conceito de História. In: Obras escolhidas I: magia e técnica, arte e política. São Paulo: Brasiliense, 1996

3 BENJAMIM, Walter. O narrador. In: Obras escolhidas I: magia e técnica, arte e política. São Paulo: Brasiliense, 1996, p. 214.P. 197

4 FREIRE, Paulo. A importância do ato de ler. $23^{\text {a }}$ Ed. São Paulo: Autores Associados; Cortez, 1989, p. 11.

5 RICOEUR, Paul. O si-mesmo como um outro. Campinas: Papirus, 1991, p. 138,139 .

6 DILTHEY, Wilhelm. A construção do mundo histórico nas ciências humanas. São Paulo: Editora da UNESP, 2010, p. 161.

7 BENJAMIN, Walter. O narrador. In: Obras escolhidas I: magia e técnica, arte e política. São Paulo: Brasiliense, 1996, p. 214.

Resenha recebida em junho de 2017. Aceita em julho de 2017. 